\title{
Solitary squamous papilloma of the bronchus
}

\author{
RJ MAXWELL, JR GIBBONS, MD O'HARA \\ From the Departments of Surgery, Thoracic Surgery, and Pathology, Queen's University of Belfast, Belfast
}

ABSTRACT A case of solitary squamous papilloma of the bronchus is described and 11 other cases from the reports published worldwide are reviewed. These tumours present in middle aged men with symptoms similar to those of bronchial carcinoma. Treatment by bronchoscopic removal or lobectomy is usually curative. Symptoms are similar to those of bronchial carcinoma, but a correct preoperative diagnosis permits more conservative surgery to be carried out. Difficulties in the histological classification of papillary tumours of the bronchus are discussed.

Squamous papillomas are the most common of the benign tumours of the larynx. They usually occur in children, are multiple, and may spread to affect the bronchi. In contrast, solitary squamous papilloma arising in the bronchus is one of the rarest pulmonary tumours.' In this paper we report a case and review the reports published worldwide.

\section{Case report}

A 74 year old man with a previous history of mild chronic bronchitis presented with increasing shortness of breath on exertion for one year. During this time he had a cough productive of thick white sputum, for which several courses of antimicrobial agents had been prescribed by his family doctor. On several occasions during the previous six months he had noted pink staining of the sputum. There had been a weight loss of $10 \mathrm{~kg}$ during 18 months. He had smoked 20 cigarettes a day for some 50 years.

On examination he was thin but looked quite fit for his age. There was moderate finger clubbing. The pulse was 80 beats/min and regular and the blood pressure $100 / 65 \mathrm{~mm} \mathrm{Hg}$. The trachea was central and apart from bilateral basal coarse crepitations there were no abnormal signs in the chest. The haemoglobin concentration was $10.4 \mathrm{~g} / \mathrm{dl}$ and the erythrocyte sedimentation rate (Westergren) was $134 \mathrm{~mm}$ in the first hour. Chest radiographs showed a $6.0 \mathrm{~cm}$ opacity in the right lower lobe.

At bronchoscopy a fleshy tumour was seen in the right lower lobe bronchus and a biopsy specimen was taken. The histological appearance was that of a

Address for reprint requests: Mr JRP Gibbons, Department of Thoracic Surgery, Royal Victoria Hospital, Belfast BT12 6BA.

Accepted 27 July 1984 bronchial papilloma with some surface dysplasia. No evidence of malignancy was found. After clinical assessment and respiratory function tests he was considered fit for surgery. At thoracotomy the right lower lobe was quite solid and adherent to the diaphragm. Some enlarged hilar lymph nodes were noted. A lower lobectomy was carried out, the hilar nodes being removed with the specimen. His postoperative course was uneventful and he remains in good health three years later.

\section{PATHOLOGY}

Gross specimen The lower lobe weighed $440 \mathrm{~g}$ and measured $13 \times 9 \times 5 \mathrm{~cm}$ (fig 1). The pleura showed areas of fibrous thickening associated with adhesion formation between the visceral and parietal layers. On section the lower lobe bronchus was enormously dilated by a mass of pale, friable papillomatous tumour measuring $5 \times 4 \times 3 \mathrm{~cm}$, arising from the bronchial mucosa and extending almost to the limit of excision. The lung parenchyma distal to the lesion showed features of chronic inflammation with atelectasis and fibrosis.

Microscopic examination (figs 2 and 3) Histologically the mucosal lining of the distended bronchus showed extensive areas of squamous metaplasia. The tumour consisted of large numbers of papillomatous fronds, all lined by hyperplastic squamous epithelium showing moderate parakeratosis and hyperkeratosis. In a few areas mild dysplasia, as characterised by heaping up of nuclei, cellular atypism, and mitotic activity, was noted but no carcinoma in situ or invasive squamous carcinoma was present. No inclusions similar to those seen in viral warts of the skin were visible. Distal to the tumour there was a retention pneumonia with atelectasis 


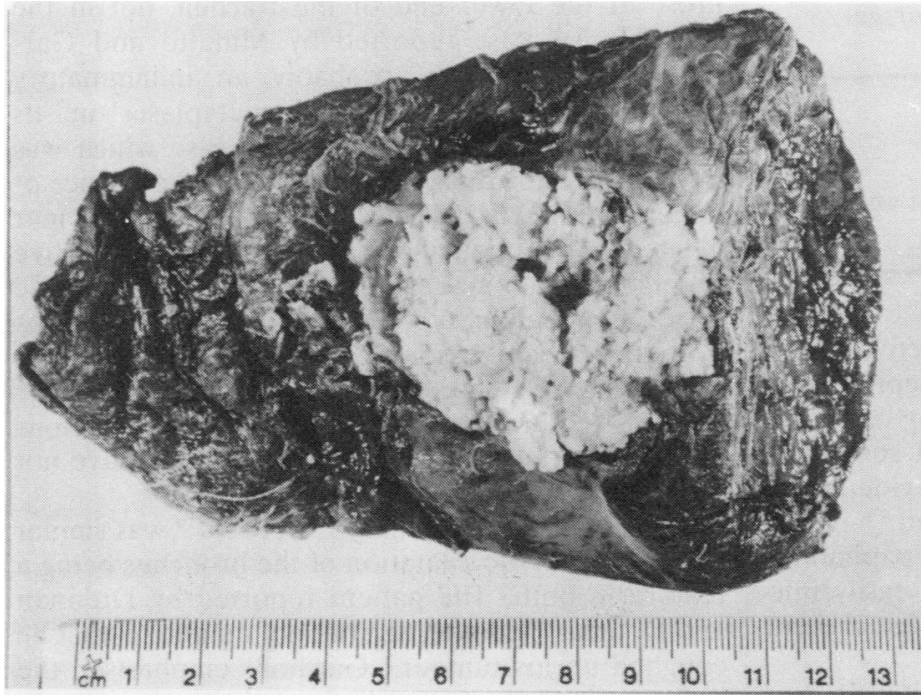

Fig 1 Right lower lobectomy specimen. The main bronchus shows distension by a soft friable papillomatous tumour mass.

and pulmonary and pleural fibrosis. No asbestos bodies were noted. The bronchial mucosa at the limit of excision was of the normal columnar, ciliated variety. Hilar lymph nodes showed reactive changes and moderate anthracosis.

\section{Discussion}

Jackson and Jackson ${ }^{2}$ in 1932 referred in their discussion of benign tumours of the trachea and bronchi to the "utter chaos" existing in the histological classification of these tumours. In no group was the confusion greater than among the papillomas. The classification used by Drennan and Douglas, ${ }^{3}$ who divided these into three groups, helped to clarify the problem. Their first group, the commonest type,

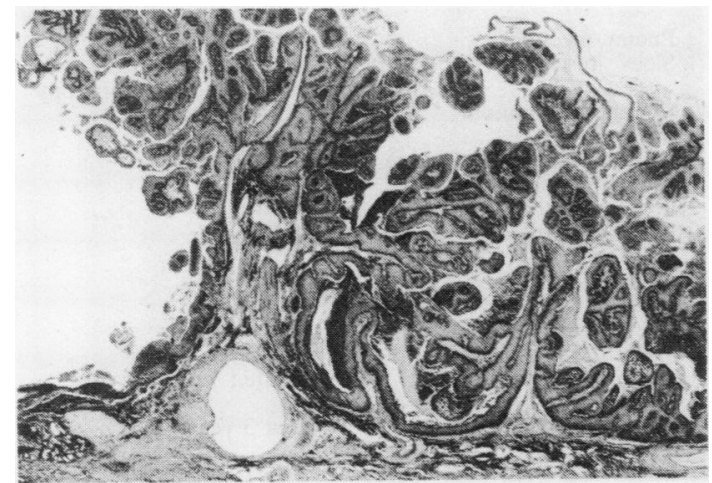

Fig 2 Papillomatous processes are lined by feebly keratinised squamous epithelium. (Haematoxylin and eosin, $\times 6$. includes the multiple squamous papillomas affecting larynx, trachea, and bronchi in decreasing order of frequency. These are usually seen in childhood and a characteristic feature of the laryngeal lesion is its tendency to regress spontaneously. A viral aetiology is thought likely. Those occurring in adults differ in that they arise almost exclusively from the vocal cords and are keratinised.

The second group comprises the inflammatory polyps arising in the mucosa of patients with chronic respiratory infection. These are covered by respiratory ciliated epithelium and have a fibrous tissue core in which oedema and inflammatory cell infiltration are prominent features. They resemble in many respects their nasal counterparts. The third group, and the rarest, are the solitary squamous papillomas.

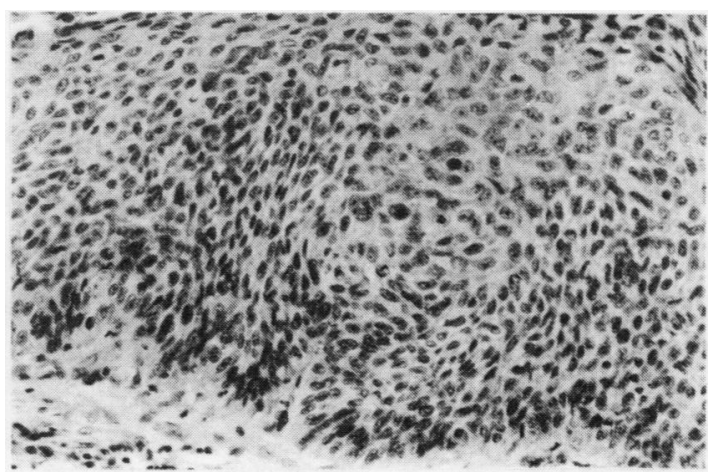

Fig 3 The squamous epithelial lining of some processes shows mild dysplastic change but no evidence of carcinoma in situ or invasive malignancy. (Haematoxylin and eosin, $\times$ 175.) 
Table 1 Classification of benign papillomas of the bronchial tree

1 Multiple papillomas (squamous)

(a) Juvenile

2 Inflammatory polyps (columnar)

3 Solitary papilloma (columnar or cuboidal with or without squamous metaplasia)

4 Solitary papilloma (squamous)

These consist of a well formed connective tissue stroma covered with stratified squamous epithelium. Solitary papillomatous lesions covered by columnar or cuboidal epithelium, with or without squamous metaplasia, but showing little or no evidence of inflammation, have also been described. ${ }^{45}$ These have some features of both squamous papillomas and inflammatory polyps but do not fit easily into either group. For this reason we have assigned them to a separate category (table 1).

A review of the reports published worldwide has yielded 11 well documented cases of solitary squamous papilloma (table 2). Histological data in some other reports have been unclear, particularly with regard to the nature of the covering epithelium and the presence of inflammatory infiltrate in the connective tissue core. A case described by Siegert ${ }^{7}$ in 1892 was of interest in that it was the earliest report, but we have excluded this as it was almost certainly an inflammatory polyp and in any case arose at the lower end of the trachea, not in the bronchus. A case reported by Minetto and Garbagni, ${ }^{8}$ likewise, was probably an inflammatory polyp with some squamous metaplasia in its epithelium. Ashmore ${ }^{4}$ described a case which was morphologically a papilloma and lacked evidence of inflammation but its epithelium was of columnar ciliated type. Freant and Sawyers ${ }^{9}$ have reported five bronchial papillomas and, while they state that these were of squamous type, a full histological description of each case was not given. Further, they imply that Ashmore's case was of the same type as their own cases, although it was clearly not a squamous papilloma. Because of this uncertainty we have not included these patients.

The tumour described by Elliot $e a{ }^{10}$ was similar to our case, cystic dilatation of the bronchus being a feature in both. The patient reported by Drennan and Douglas ${ }^{3}$ was unusual, but not unique, in that he

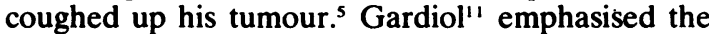
difficulty in excluding malignancy in some cases; in fact, in his first patient carcinoma was diagnosed from the bronchoscopic biopsy specimen, this diagnosis being revised when the resected lung was examined. Smith and Dexter ${ }^{12}$ also referred to this problem and with their case of benign papilloma they reported eight papillary bronchial neoplasms which they considered to be of low grade malignancy. Dybicki et al ${ }^{13}$ described a squamous papilloma "turning malignant." The first case of Jackson

Table 2 Reports of benign solitary squamous papilloma of the bronchus

\begin{tabular}{|c|c|c|c|c|c|}
\hline Authors & Age (y) & Presenting symptoms & $\begin{array}{l}\text { Site of } \\
\text { papilloma }\end{array}$ & Treatment & Outcome \\
\hline \multirow[t]{3}{*}{ Gardiol 1959"1 } & 60 & \multirow{3}{*}{$\begin{array}{l}\text { Chronic cough, febrile } \\
\text { illness, dyspnoea } \\
\text { Chest pain, weight } \\
\text { loss } \\
\text { Chronic cough, chest } \\
\text { pain }\end{array}$} & RULB & \multirow{3}{*}{$\begin{array}{l}\text { Radiotherapy, } \\
\text { pneumonectomy } \\
\text { Resection of upper and } \\
\text { middle lobes } \\
\text { Bronchoscopic removal }\end{array}$} & Postoperative death \\
\hline & 56 & & RUBL & & Operative death \\
\hline & 72 & & RLLB & & $\begin{array}{l}\text { Died at } 4 \text { months, } \\
\text { bronchopneumonia; no } \\
\text { evidence of tumour at necropsy }\end{array}$ \\
\hline \multirow{4}{*}{$\begin{array}{l}\text { Elliott et al } 1962^{10} \\
\text { Smith and Dexter } \\
1963^{12} \\
\text { Drennan and Douglas } \\
1965^{3} \\
\text { Jackson and Hatch } \\
1968^{14}\end{array}$} & \multirow{2}{*}{$\begin{array}{l}52 \\
\text { middle- } \\
\text { aged } \\
56\end{array}$} & \multirow{2}{*}{$\begin{array}{l}\text { Cough, haemoptysis } \\
\text { Haemoptysis } \\
\text { Wheezing, dyspnoea }\end{array}$} & $\begin{array}{l}\text { LLLB } \\
\text { RULB }\end{array}$ & $\begin{array}{l}\text { Pneumonectomy } \\
\text { Sleeve resection }\end{array}$ & \multirow{2}{*}{$\begin{array}{l}\text { Well at } 2 \text { years } \\
\text { Recurrent haemoptysis at } 2 \\
\text { years; refused bronchoscopy } \\
\text { Well at } 3 \text { years }\end{array}$} \\
\hline & & & ?LLLB & Coughed up tumour & \\
\hline & 51 & $\begin{array}{l}\text { Myocardial infarction, } \\
\text { shadow on chest } \\
\text { radiograph }\end{array}$ & LLLB & $\begin{array}{l}\text { Upper lobectomy (abscess), } \\
\text { bronchoscopic removal, } \\
\text { lower lobectomy }\end{array}$ & Well at 17 years \\
\hline & 51 & $\begin{array}{l}\text { Cough, haemoptysis, } \\
\text { pneumonia }\end{array}$ & RULB & Bronchoscopic removal & Well at 1 year \\
\hline Laubscher $1969^{\circ}$ & 74 & $\begin{array}{l}\text { Haemoptysis, chest } \\
\text { pain, weight loss }\end{array}$ & Lingula & Upper lobectomy & Well at 3 years \\
\hline \multirow[t]{2}{*}{ Spencer et al $1980^{\prime s}$} & 28 & $\begin{array}{l}\text { Chest pain, productive } \\
\text { cough }\end{array}$ & RULB & Upper lobectomy & Alive at 18 years \\
\hline & $38^{*}$ & Recurrent pneumonia & $\begin{array}{l}\text { ULB } \\
\text { ? side }\end{array}$ & Upper lobectomy & Not stated \\
\hline Present study & 74 & $\begin{array}{l}\text { Dyspnoea, } \\
\text { haemoptysis, weight } \\
\text { loss }\end{array}$ & RLLB & Lower lobectomy & Well at 3 years \\
\hline
\end{tabular}

*Female.

LULB - left upper lobe bronchus; RULB—right upper lobe bronchus; ULB—upper lobe bronchus; RLLB—right lower lobe bronchus; LLLB-left lower lobe bronchus. 
and Hatch ${ }^{14}$ had a complex medical history, having initially had bronchoscopy and biopsy of a lesion in the left upper lobe bronchus. At first this was reported as carcinoma, but review showed only metaplasia and at lobectomy there was an abscess with no evidence of carcinoma. One year later the patient had a squamous papilloma of the left lower lobe bronchus which could be only partially removed at bronchoscopy and therefore the remainder of the left lung was subsequently excised. Spencer $e^{t} a^{15}$ have reviewed 19 non-invasive papillary tumours. Of the benign solitary papillomas, two were covered entirely by a squamous epithelium. These patients were unusual in that both were much younger than the other patients we reviewed and one, aged 38 years, was the only woman in our review. A further two of their cases, however, were similar except that in each there was a small focus of carcinoma in situ, for which reason they have been excluded from this study. We have found difficulty in interpretation of some of the previous reports because of variation between pathologists in the description of benign and borderline malignant features.

Although this series is small, some conclusions can be drawn. All the patients except one were men and all except two were aged from 51 to 74 years. Symptoms were commonly a result of bronchial obstruction and secondary infection. Haemoptysis was a feature in almost half the cases. Four patients were smokers, one was not, and in the remaining eight a smoking history was not given. There was no predilection for upper or lower lobe bronchi or for right or left lung. Bronchoscopic removal of the tumour was performed in three patients, but was incomplete in one, who later had a lobectomy. Eight patients had resection of a lobe or lung. In two of the three patients having pneumonectomy this was done in the belief that the patient had a carcinoma. The outcome was good in those who survived the postoperative period. There was no proved recurrence of a completely removed tumour, but one patient did develop haemoptysis two years after sleeve resec- tion. Unfortunately he refused bronchoscopy.

Solitary squamous papilloma of the bronchus, a very rare tumour, occurs predominantly in men of the same age group as those developing bronchial carcinoma, and presents with similar symptoms. At bronchoscopy a small tumour may be removed or a larger one biopsied. A correct preoperative diagnosis makes more conservative surgery possible and the prognosis is good in those fit enough to withstand thoracotomy.

\section{References}

1 Spencer H. Pathology of the lung. Vol. 2. 3rd ed. Oxford: Pergamon Press, 1977;884-7.

2 Jackson C, Jackson CL. Benign tumors of the trachea and bronchi. JAMA 1932;99:1747-54.

3 Drennan JM, Douglas AC. Solitary papilloma of a bronchus. J Clin Pathol 1965;18:401-2.

4 Ashmore PG. Papilloma of the bronchus. J Thorac Surg 1954;27:293-4.

5 Memon AM, Ramisetti DK, Ayvazian LF. Mobile bronchial papilloma spontaneously expectorated. J Med Soc NJ 1978;75:409-11.

6 Laubscher FA. Solitary squamous cell papilloma of bronchial origin. Am J Clin Pathol 1969;52:599-603.

7 Siegert F. Ueber Primäre Geschwülste der unteren Luftwege. Virchows Arch (Pathol Anat) 1982; 129:413-25.

8 Minetto E, Garbagni R. A propos du papillome bronchique. Ann Otolaryngol 1954;71:642-9.

9 Freant LJ, Sawyers JL. Benign bronchial polyps and papillomas. Ann Thorac Surg 1971;11:460-7.

10 Elliott GB, Belkin A, Donald WAG. Cystic bronchial papillomatosis. Clin Radiol 1962;13:62-7.

11 Gardiol D. Le Papillome bronchique isolé de P'adulte. Oncologia 1959;12:304-16.

12 Smith JF, Dexter D. Papillary neoplasms of the bronchus of low-grade malignancy. Thorax 1963;18:340-9.

13 Dybicki J, Zmarzlik Z, Dabrowski J, Tokarczyk T. Isolated bronchial papillomas. Pol Med J 1972;11:380-7.

14 Jackson DA, Hatch HB. Solitary benign squamous papilloma of the bronchus. Am Rev Respir Dis 1968;97:699-705.

15 Spencer H, Dail DH, Arneaud J. Non-invasive bronchial epithelial papillary tumors. Cancer 1980;45: 1486-97. 